\title{
The Introduction of Active Learning Methodologies in Anatomy Teaching to Physical Education Course
}

\author{
Lino Pinto de Oliveira Junior ${ }^{1,2}$ \\ ${ }^{1}$ Universidade do Vale do Rio dos Sinos (UNISINOS), Porto Alegre, RS, Brazil \\ ${ }^{2}$ Universidade Federal de Ciências da Saúde de Porto Alegre (UFSCPA), Porto Alegre, RS, Brazil \\ ${ }^{3}$ Universidade de Santa Cruz do Sul (UNISC), Santa Cruz do Sul, RS, Brazil
}

João Antônio Bonatto-Costa, ${ }^{1,2}$ Jéssica Deisiane Scherer, ${ }^{1}$ Matheus Ramos, ${ }^{1}$ Matheus Ayres Melo, ${ }^{1}$ Deivis de Campos,,${ }^{2,3}$

Disclose and conflicts of interest: none to be declared by all authors

\section{ABSTRACT}

Introduction: introduction: Due to the constant evolution of technology and the easy access to information, it is prudent to pursue opportunities for new teaching-learning methodologies within the university. This study aimed to evaluate the results of the students' approval and achievement in a discipline of anatomy using active learning methodologies.

Methods: anatomophysiology of Organic Systems classes from 2014, 2015, and 2016 have been analyzed to compare the final grades and the failure rate of the students after starting active learning methodologies. The students formed groups that received weekly sets of questions to be researched and discussed, according to the subjects presented in class. The weekly meetings were divided into four parts. In the first part, the groups would present for the class the assignments given to them in the previous week. In the second part, the teacher would lecture on a new subject, and then, in the third part, the students would be encouraged to pursue knowledge that is complementary to the subject discussed in this lecture, according to individual interest. Finally, new assignments were given to the groups.

Results: the results showed that active learning methodologies decreased the failure rates by $15 \%$ and even increased the general averages of the students by $8 \%$.

Conclusion: the active learning methodologies approach can help in the learning process of human anatomy. However further studies and application by the teaching staff of higher education institutions are needed to validate the method.

Keywords: Active learning; Group learning; Active methodology.

\section{Introduction}

Historically, the dissemination of knowledge for the training of healthcare professionals in different universities was characterized by the use of conservative or traditional methodologies. ${ }^{1}$ Alongside this fact, the teaching-learning process was often limited to a restricted reproductive mode wherein the teacher assumes the role of content distributor and the student has the role of absorption and reproduction of the transmitted content, taking a passive posture in which he does not need to express critical and reflexive thinking during the learning process. ${ }^{2}$ In light of this background, active learning methodologies can be seen as significant improvements.

Due to the constant evolution of technology and the easy access to information, it is prudent to pursue opportunities for new teaching-learning methodologies within the university, so that the academic environment maintains relevance to the always-connected, information-rich reality of the modern student's world. ${ }^{3}$

All these issues should be considered, especially when discussing the teaching of human anatomy, an essential discipline for the training of the healthcare professional since classical antiquity. ${ }^{3}$ However, many students perceive the importance of learning human anatomy only when they are confronted in real life with the need for anatomy knowledge or when they are close to complete a medical procedure of their interest. ${ }^{4}$

Considering that the completion of an undergraduate degree program requires only a few years, a short time relative to the duration of a professional career, it is necessary that students are capable of "learning how to learn" and to actively develop solutions to problems they will face throughout their careers. Given this, it is important to use methodologies that enable and focus on the active participation of the student as the main agents of the teaching-learning process. ${ }^{5}$ Thus, the traditional teaching model has been gradually replaced by pedagogical tendencies that foster the creation of professionals with critical and reflective thinking. ${ }^{6}$

In this context of new tendencies, the active learning methodology is a possible strategy to amplify this scenario, since in this approach the student assumes a central role in the learning process and the teacher presents himself as a cooperative facilitator rather than simply a static knowledge transmitter. ${ }^{6,7}$ This method intends to encourage autonomy, curiosity, and both individual and collective decision-making. The teacher 
favors analytical thinking in his students by insisting that they position themselves critically, which is fundamental to social practice. Thus, the teacher must consider the educational process within the context of the students' lives overall, since education is part of it and therefore is present in their lives. ${ }^{8}$

To allow the students to develop their autonomy is not a favor, but an imperative ethical action. ${ }^{9}$ Then, it is the teacher's role to recognize the pedagogical intentionality that guides his actions and to value the protagonism of the students, considering their interests and curiosities, while providing the means to achieve the competencies expected by the discipline, making the students able to fill the gaps like a result of the method described.

Having this methodology as a goal, one of the ways that the teacher can bring such a method to the classroom in the teaching of human anatomy is through problem-based learning (PBL). PBL is a teaching-learning methodology that is utilized to solve a problem (or question) as a motivation for the development of knowledge. In this proposal, the teacher is a facilitator of the learning process; it is he who gives the problem to be solved and the student is responsible for solving it. ${ }^{10}$ This responsibility is passed on by the teacher through the elaboration of the problem and it is not up to a single individual to solve it, but to a small group. The prior knowledge of each component associated with the search for the answers to the subsequent questions form the purpose of the learning and serve as individual and collective study content for the students. ${ }^{11}$

The application of active learning methodologies and problem-based learning is so widespread that there are several studies and different areas that are applying this method. Widely used in the field of medicine ${ }^{11}$ nowadays, active methodologies are explored in areas such as physical education, biomedical sciences, nursing, administration, engineering, and college education. ${ }^{12,13,14,15,16}$ Considering that the study of human anatomy in universities is largely taught through traditional methodologies and the failure rates are high, the objective of the present study is to evaluate and compare the students' achievement, across six semesters, in the disciplines of anatomophysiology of organic systems from the physical therapy course that used active methodologies during the schooling period.

\section{Methods}

The classes of a discipline of anatomy and physiology of the organic systems at a private university in southern Brazil during the years 2014, 2015, and 2016 were analyzed along with the final averages and the number of failures of each year. For the development of this methodology, the classes were divided into workgroups with about five participants each. In the first moment, the teacher assigned to each group a problem related to the daily life of the students, placing them in the position of an active physical education professional. In this way, the students studied and researched the themes, aiming for the improvement of the learning with the participation of all the members of the group, willing to solve the presented problem.

The next meeting was divided into four segments, starting with an initial moment of presentation and discussion of the themes proposed in the previous class (about $30 \%$ of total time). In the second moment (about 30\% of total time), the teacher would talk about a new subject, which would be the main theme of the class. In the next moment (30\% of total time), the teacher would encourage the autonomous search for complementary knowledge of the subject, out of curiosity, new questions and the interest of each student. In the final stage (10\% of total time), new problems to be studied were assigned to each group to elucidate the main theme of the following week, thus making the educational process cyclical.

In this way, the weeks followed in a continuous flow, always starting a new class from the end of the previous one, at all times with coherence and correlation with what was studied. This increased the students' interest and engagement with the subject.

\section{Results}

The results took into account the performance of the students, verified through the final average grade obtained in the discipline, and grouped in each of the evaluated years. The analysis of the number of students who failed each year was also taken into account. Students who failed for non-attendance or who dropped out of the discipline before assessments haven't been considered.

Analyzing the results of the years 2014, 2015, and 2016, there was a progressive increase in the final grades of each year. The nonparametric analysis, using Kruskal-Wallis test followed by Dunn's post test showed no significant difference between the years of 2014 and 2015. Differences were observed between 2015 and $2016(\mathrm{p}<0.01)$ and pointed to a high significant difference between 2014 and 2016 ( $p<0.0001$ ) (Figure 1).

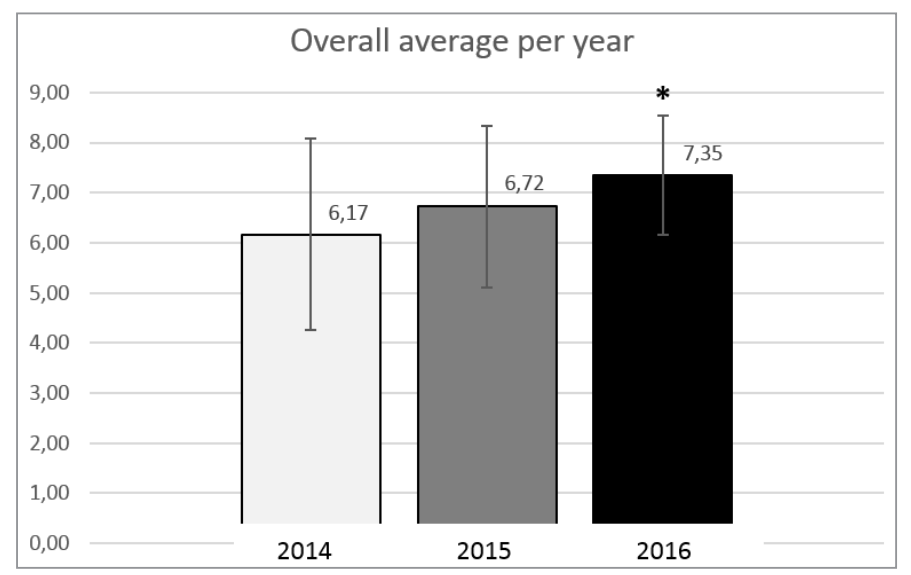

Figure 1. Overall average grade per year. 
When analyzing the number of failures, it was also possible to observe the decrease in the failure rate in the course $(\mathrm{p}<0.001)$ (Table 1$)$.

Table 1. Student total number per year, absolute number of failures per year and percentage of failures per year.

\begin{tabular}{c|c|c|c}
\hline YEAR & $\begin{array}{c}\text { Students Total } \\
\text { Number }\end{array}$ & $\begin{array}{c}\text { Number of } \\
\text { Failures }\end{array}$ & $\begin{array}{c}\text { Percentage of } \\
\text { Failures }\end{array}$ \\
\hline 2014 & 68 & 13 & $19,11 \%$ \\
\hline 2015 & 133 & 18 & $13,53 \%$ \\
\hline 2016 & 132 & 5 & $3,78 \%$ \\
\hline
\end{tabular}

\section{Discussion}

Active learning methodologies can be conceptualized and applied in different ways. Problembased learning (PBL) is a process through which the student acquires knowledge by attempting to solve unstructured problems, such as what can occur outside the classroom. ${ }^{17}$ Similar to this, the problemsolving method, first referenced by The Maguerez Arch, aims, in addition to solving through hypotheses, the application of solutions, placing the students as active members in their society. ${ }^{18}$

In the peer instruction method, the approach facilitates learning through discussion in pairs or small groups, exercising students' knowledge and ability to debate $(19,20)$, similar to team-based learning (TBL), where the teams discuss amongst themselves the results that each one achieved after internal discussion. ${ }^{21}$ Thus, we could not characterize the methodology developed in the discipline, completely, in none of the conceptualized methodologies above, but actually, a combination of the different techniques described.

In the present study, we observed a significant decrease in the number of failing students in the discipline of anatomophysiology of organic systems after the implementation of an active learning methodology for teaching the discipline. One of the methodologies used in this study was learning in pairs or groups. This method shows that students who participate in these activities tend to have higher scores in their final exams compared to those who do not attend the groups. ${ }^{22}$

In addition to a higher pass rate, the final grades were around $9 \%$ higher than in the previous year, i.e., an approximate increase of $20 \%$ compared to the beginning of the evaluation. This result corroborates another study ${ }^{23}$ which shows that the number of students with grades above $80 \%$ of achievement, increased by $15 \%$ compared to those educated by the traditional method of teaching. Students who used the active learning method obtained higher final scores than those who used the conventional form of teaching. 22,23

When students are exposed to active learning methodologies, after the use of conventional teaching methods, the vast majority prefers the active method. ${ }^{24}$ Although we did not evaluate this preference, the greater attention and commitment from the students during the learning process was noticeable.

Other studies do not present significant results when comparing the conventional method to the active method ${ }^{25}$ but the students showed a small increase in their final grades and mentioned that the active method was more beneficial to the learning process, allowing greater flexibility of reasoning. On the other hand, participants of a Canadian study claimed fewer cognitive requirements for learning when using the active methodology. ${ }^{26}$

The use of preparatory exercises for the following classes was also carried out in other studies ${ }^{27}$ and had a positive response from the students, who declared that they were better prepared for the subject of the lesson, although only a minority have reported that this method has increased their interest in the subject.

Although it was not analyzed in this study, we noticed that in the first year of application of the active learning methodology, there were still many students who gave up during the first year, and then in the following years, a significant difference was observed in the number of dropouts. This fact was also mentioned by Lasry et al., ${ }^{28}$ and related to the beginning of the use of the active method. Considering the political, economic, and educational reality of our country, as well as the investments and expectations created by our students, the decrease in dropouts and failures becomes a very important element for the maintenance and improvement of the mentioned teaching methodology.

The results found in this present study, compared with other studies, show the relevance of the use of active methodologies in terms of improvement in learning and consequently in students' final grades. Even in studies that do not present significant results, students exposed to active methodologies never showed lower grades or preference for traditional teaching.

Furthermore, the teacher changes his role from holder and transmitter of knowledge to a facilitator of the learning process, and for such change to occur, a transitional period of adjustment to this new proposal is necessary, since a large percentage of teachers are still not familiar with this process. This was made clear to us by observing the continuous progression of the values evaluated in the three years of monitoring. As the study of González-Hernando et al. ${ }^{29}$ corroborates the present one, it shows that the teacher with more experience in the active methods presents a better result than the one who is only trained to apply the method and therefore doesn't have as much experience.

Finally, it can be said that the use of active methodologies can help both students and teachers in the process of learning and teaching human anatomy, and that a subsequent study is necessary to quantify and qualify the real consolidations of the contents, by the students, during the use of active methodologies. 


\section{References}

1. Capra Fritjof. O ponto da mutação: a ciência, a sociedade e a cultura emergente. $1^{\text {a }}$ ed. Cultrix: São Paulo; 1986, $30^{\text {a }}$ reimpressão 20Behrens MA. O paradigma emergente e a prática pedagógica. v. 80 Petrópolis 2005: 383-403

3. Fornaziero CC, Gordan PA, Carvalho MA, Araujo JC, Aquino JCB. O ensino da anatomia: integração do corpo humano e meio ambiente. Rev Bras Ed Med 2010;34:290-297.

4. Gardner et al. Anatomia Geral: Anatomia Estudo Regional do Corpo Humano. 13 ed. Rio de Janeiro: Guanabara Koogan; 1971:3-9.

5. Fernandes JD et al. Estratégias para a implantação de uma nova proposta pedagógica na escola de enfermagem da Universidade Federal da Bahia. Rev Bras Enf 2003;56:392-397.

6. Rodrigues J, Zagonel IPS, Mantovani MF. Alternativas para a prática docente no ensino superior de enfermagem. Escola Anna Nery 2007;11:213-220.

7. Prado ML, Reibnitz KS, Inovação e educação em enfermagem. Florianópolis; 2006.

8. Borges TS, Alencar G. Metodologias Ativas Na Promoção Da Formação Crítica Do Estudante: 0 uso das Metodologias Ativas como recurso didático na formação crítica do estudante do Ensino Superior. Cairu em Revista 2014;3:119-143.

9. Freire P. Pedagogia da autonomia: saberes necessários à prática educativa. São Paulo: Paz e Terra, 1996.

10. Graaf E, Kolmos A. Characteristics of problem-based learning, Int J Eng Edu 2003;5:657-662.

11. Batista $\mathrm{N}$ et al. $\mathrm{O}$ enfoque problematizador na formação de profissionais de saúde. Rev Saúde Pub 2005;39:231-238.

12. Hermes FC, Cutolo LRA, Maestrelli SRP. A Concepção de Estudantes de Fisioterapia que Participam do Ensino Baseado em Problemas sobre o Processo Saúde-Doença. Rev Bras Ed Med 2016;40:627-634.

13. Marin MJS et al. Fazendo e aprendendo: uma experiência de ensino/aprendizagem. Rev Bras Enf 2004;57:75-78.

14. Escrivão Filho E, Ribeiro LRC. Inovando no ensino de administração: uma experiência com a aprendizagem baseada em problemas (PBL). Cadernos EBAPE.BR 2008;6:01-09.

15. Ribeiro LRC, Mizukami MG. An experiment with PBL in higher education as appraised by the teacher and students. Interface 2005;9:357-368.

16. Ferreira $C$, Alencoão $A$, Vasconcelos $C$. $O$ recurso à modelação no ensino das ciências: um estudo com modelos geológicos. Ciência \& Educação 2015;21:31-48.

17. Guerra A. Problem Based Learning and Sustainable Engineering Education: Challenges for 21st century [Ph.D. dissertation]. Denmark: Aalborg University; 2014.

18. Berbel N.A.N. Metodologia da Problematização: uma alternativa metodológica apropriada para o Ensino Superior. Semina: Ciencia Social e Humana 1995;16:9-19.

19. Crouch CH, Mazur E. Peer Instruction: Ten years of experience and results. Am J of Physics 2001;69:970-977.

20. Crouch CH et al. Peer Instruction: Engaging students one-onone, all at once. Research-based Reform of University Physics 2007;1:1-55. 21. Farias PAM, Martin ALAR, Cristo CS. Aprendizagem Ativa na Educação em Saúde: Percurso Histórico e Aplicações. Rev Bras Ed Med 2015;39:143-150.

22. Bruno PA et al. Students helping students: Evaluating a pilot program of

peer teaching for an undergraduate course in human anatomy. Anat Sci Educ 2016;9:132-142.

23. Wang J. et al, Problem-Based Learning in Regional Anatomy Education at Peking University. Anat Sci Educ 2010;3:121-127.

24. Dope SA, Mungal SU, Kulkarni PR. Problem Based Learning in I MBBS Anatomy, ScopeMed 2013;3:50-56.

25. Khaki AA et al, The First Year Medical Students' Perception of and Satisfaction from Problem-based Learning Compared to Traditional Teaching in Gross Anatomy: Introducing Problem-based Anatomy into a Traditional Curriculum in Iran, Int J Health Sci 2007;1:113-118.

26. Gross MM, Wright MC, Anderson OS. Effects of Image-Based and Text-Based Active Learning Exercises on Student Examination Performance in a Musculoskeletal Anatomy Course. Anat Sci Educ 2017;10:444-455.

27. Wall ML, Prado ML, Carraro TE. A experiência de realizar um Estágio Docência aplicando metodologias ativas. Acta Paulista de Enfermagem 2008;21:515-519.

28. Lasry N, Mazur E, Watkins J. Peer instruction: From Harvard to the two-year college. Am J of Physics 2008;76:1066-1069.

29. González-Hernando C et al, Evaluación por los estudiantes al tutor de enfermería en el contexto del aprendizaje basado en problemas, Enfermería Universitaria 2015;12:110-115.
Received: Octuber 20, 2020

Accepted: January 5, 2021
Corresponding author

João Antônio Bonatto-Costa

E-mail: jbonatto@unisinos.br 